\title{
In Honor of the Comstocks of Cornell
}

\section{AT CORNELL UNIVERSITY.}

Comstock Hall, Cornell Entomology Headquarters.

The John Henry Comstock Memorial Library of Entomology.

Anna Botsford Comstock Hall, a Cornell dormitory.

The Comstock Publishing Company, a gift to Cornell University by Professors J. H. and A. B. Comstock and S. H. Gage. This gift included the Company's copyrights, equipment, and the lands and buildings now occupied by the Cornell University Press and by the Comstock Associates, a division of the Cornell University Press.

Cornell University's Graduate Fellowships, financed in part by a gift from the estates of John Henry Comstock and Anna Botsford Comstock.

Comstock Knoll, the hill on the southeast boundary of Beebe Lake, now part of the Cornell Plantations.

Portrait of the Professors John Henry and Anna Botsford Comstock. This portrait is in the Reading Room of the Cornell University Library.

\section{AT ITHACA AND ELSEWHERE.}

Anna Botsford Comstock Camp for Girl Scouts, on the shore of Cayuga Lake.

Mrs. Comstock's portrait at William Smith College, Geneva, New York.

Memorial stained glass window in memory of Mrs. Comstock, presented to the Unitarian church of Ithaca, by Mr. and Mrs. George H. Russell.

RUby GreEN SMith 